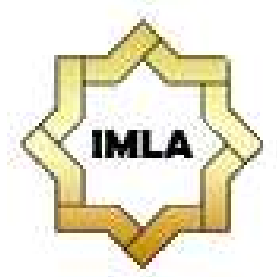

Al-Ta'rib

Jurnal Ilmiah Program Studi Pendidikan Bahasa Arab

IAIN Palangka Raya

Vol. 9, No. 1, June 2021, 13-24

p-ISSN 2354-5887 | e-ISSN 2655-5867

DOI: https://doi.org/10.23971/altarib.v9i1.2578

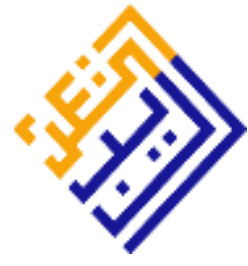

\title{
TRACING THE DEVELOPMENT OF ARABIC KHAT FROM THE LAND OF ORIGIN TO INDONESIAN ARCHIPELAGO
}

\author{
Azkia Muharom Albantani', Ahmad Adhia Adha', \\ Aida Mushoffa ${ }^{3}$, Helya Syafiroh ${ }^{4}$ \\ 1,2,3,4Universitas Islam Negeri Syarif Hidayatullah Jakarta, Indonesia \\ E-mail: azki@uinjkt.ac.id
}

\begin{abstract}
Several studies showed that Arabic khat had been widely developed in countries with a Muslim majority population. However, many previous studies have not examined the origin of the Arabic khat and its development from different periods. Therefore, this study aimed to identify the source of Arabic khat, the product and the figures from different periods, and several other things related to Arabic khat. This research was done in qualitative research with a descriptive historical approach through a literature-based study to examine data and information. The research was conducted by limiting the study's scope on Arabic khat development from the Umayyad dynasty to its expansion in Indonesia. The results showed that the Arab Khat began to develop centuries ago during the Umayyad dynasty. Three factors caused calligraphy to increase: the influence of power expansion, the kings and social elites' role, and the influence of science development. Moreover, the encouragement coming from the verses of al-Qur'an, the motivation to write al-Qur'an, and the use of Arabic as alQur'an language are also the factors in the development of Arabic khat. Hence, it is no wonder that the term Arabic khat is synonymous with al-Qur'an's khat.
\end{abstract}

Keywords: Arabic khat; history; Umayyad Dynasty; Abbasid Dynasty

\section{Abstrak}

Beberapa penelitian telah menunjukkan bahwa khat Arab banyak berkembang di negara dengan mayoritas penduduk muslim. namun, belum banyak penelitian sebelumnya yang mengkaji asal usul khat arab dan perkembangannya dari masa ke masa. Oleh karena itu, Penelitian ini bertujuan untuk mengidentifikasi tentang asalasul terlahirnya khat Arab, perkembangannya dari masa ke masa beserta tokohtokohnya, dan beberapa hal yang terkait dengan khat Arab. Penelitian ini merupakan penelitian kualitatif dengan pendekatan historis deskriptif melalui pengkajian data dan informasi berbasis kepustakaan. Penelitian dilakukan dengan membatasi ruang lingkup kajian tentang perkembangan khat Arab sejak kepemimpinan Dinasti Umayyah hingga berkembang di Indonesia. Hasil kajian menunjukkan bahwa Khat Arab mulai berkembang sejak berabad-abad yang lalu, yang mana dimulai sejak pemerintahan Dinasti Umayyah. Faktor-faktor yang menyebabkan kaligrafi berkembang pesat ada tiga, yaitu pengaruh ekspansi kekuasaan, peranan raja dan elite sosial, dan pengaruh perkembangan ilmu pengetahuan. Selain itu, semangat 
yang bersumber dari ayat-ayat Al-Qur'an, motivasi menulis Al-Qur'an, dan bahasa Arab sebagai bahasa Al-Qur'an juga menjadi faktor perkembangan khat Arab. Oleh karena itu, tidak heran jika sebutan khat Arab identik dengan khat Al-Qur'an.

Kata Kunci: khat Arab; Sejarah; Dinasti Umayyah; Dinasti Abbasiyah

\section{Introduction}

The knowledge of the Arabic khat development is essential to broaden the activist's horizons in studying the Arabic language and culture. Sirojudin's research (2020) shows that Arabic khat development has a long period with particular characteristics and colors. Furthermore, the effect of Arabic khat also brings enthusiasm to instill the normative values of al-Qur'an (Sarif, 2016; Teparic, 2014). Even an understanding of Arabic khat can support one's proficiency in writing Arabic (Ni'mah, 2019). Thus, this insight needs to be comprehended by Arabic language study activists to understand Arabic better comprehensively.

However, Arabic khat development is still not fully understood by the Arabic language and culture reviewers in general. Arabic khat, as part of Arab culture, develops with the development of science and technology, and even these developments have contributed to the study of Islamic aesthetics (BAYAR \& SAMI, 2009; Pujiati, 2016; Yaghan, 2020). Besides, Arabic khat is often considered to have developed along with Islam's development because the sentences used in khat primarily refer to al-Qur'an and Hadith. (Patriani, 2017). Arabic khat is not considered as mere writing, but it is reckoned as a medium to convey the knowledge value, educational value, aesthetic value, and idea value. (Maryono, 2018). Thus, this understanding needs to be further explored to enrich the repository Islamic Arabic language and culture studies.

Several studies have shown that Arabic khat has developed in many Muslim majority countries. Still, there have been a few studies that reviewed its origin and its development from different periods. For example, Sadewa (2018) states that Arabic khat is widely used to embellish mosques as the Muslims' places to worship. Arabic khat can even help develop the Muslim community's skills in producing fine Islamic arts (Alashari et al., 2019; Ikhwan et al., 2017). Therefore, studying the origin and development of Arabic khat from different periods is interesting to learn profoundly.

Several studies have clearly shown that Arabic khat has developed rapidly, even though it tends more towards contemporary studies. For that reason, this research was aimed to identify the origin of Arabic khat, the development and the figures in different periods, and several other things related to Arabic khat. After describing the research results, further academic considerations, practical implications, and recommendations for future studies would be discussed.

\section{Method}

This research was qualitative research with a descriptive historical approach through literature-based study to examine data and information. The literature sources used as the primary and secondary sources in this study comprised journal articles, reference books, research reports, and other literature sources related to the history of Arabic khat development. The research was conducted by limiting the study's scope on Arabic khat development from the Umayyad dynasty to its 
expansion in Indonesia. All data were then analyzed using descriptive analysis techniques to analyze and describe the investigation period's findings. Data analysis began with collecting data, categorizing data, formulating data, and describing data interpretation results.

\section{Result and Discussion \\ An Overview of Arabic Khat}

Etymologically, the definition of khat (Arabic calligraphy) originates from the Greek calls, which means beautiful, and graphein, which means writing (Sarif, 2016), which simplified in English into calligraphy (Soraya, 2012). This word means "the art of writing beautifully," and these exquisite writings become an art, that is, khat (Iskandar, 1989).

Terminologically, the definition of khat refers to a science that introduces single letterforms, locations, and how to assemble them into structured writing. In other words, khat is about what is written on lines, how to write it, how to determine what should and should not be written, how to change the necessary and unnecessary spelling, and how to choose the way to change it (Sarif, 2016).

The art of khat definition refers to writing Arabic or Jawi letters, which produces exquisite writing. This finesse is defined as "the art of writing beautifully with a pen," which is also called Fann al-Khat, meaning the art of refining writing or repairing a stroke. (Madkur, 1995).

From the definitions above, it could be inferred that the art of khat was writing which was written beautifully using Arabic letters as the main letters, and it was ornamented by attractive decorations or patterns so that it produced exquisite and fancy writing to be enjoyed as a unique and exciting work of art.

Some scholars argue that the Arabic letters are a fraction of the Syriac alphabet since there are similarities between those two language alphabets. Meanwhile, some orientalists who hold on to the theory of Lidzbarsky (a German scientist) argue that the Arabic alphabet originates from the Phoenician alphabet. (Didin Sirojudin A. R., 1992; Mansour, n.d.).

Arabic khat is not only beautiful and refined art but also pleasing to human hearts and feelings. It is the creation of Allah S.W.T. or something that results from the human mind or imagination. According to Ibn Khaldun, calligraphy is a painting and a literal form that shows the sentence heard, implying something that resides in the human soul (Auliya \& Shokiyah, 2013).

\section{The Origin of Arabic Khat}

For Arabs, writing was not the most important thing. In the past, Arabs were prouder of their excellent oral poetry than of their beautiful writing. In the early era of Islam, al-Qur'an was only memorized by Prophet Muhammad's companions. AlQur'an was just written after many hafizes had died on the battlefield. Although the Arabic alphabet was estimated to appear a century before Islam came, Arabic calligraphy only appeared in the second and third centuries of Hijri Year. (Hanifa, 2013). Thus, calligraphy finally obtained its position in Islam since its purpose was to embellish Allah's words.

The art of khat was born at the same time as the birth of Islam. The revelation received by Prophet Muhammad was written by the companions using leaves, 
bones, wood, and others until the al-Qur'an was revealed entirely in approximately 23 years.

From different periods, starting from the Prophet Muhammad's era to the present day, this art was progressively growing, and more khat experts have produced various types and forms of khat. One hundred years after Prophet Muhammad had died, this art reached the peak of its glory. The khats (the term for khat experts) were honored and respected, and they also gained considerable authority throughout the Islamic world.

The role of khat was to perpetuate al-Qur'an in written form and conserve some of the al-Qur'an verses in mosques, houses, and other places. The khats came from Arabs, but they are also from countries with many Muslim descendants around the world, such as French, Turkey, India, Africa, Malay-majority countries, and so forth. They enriched their khat by introducing various styles and new forms, especially in the $7^{\text {th }}$ to $10^{\text {th }}$ centuries CE. This art has increased throughout the world along with the development of Islamic preaching. and Islamic sciences. With the entry of Arabic as an international language, this art's story would be faster.

The following were several opinions regarding the origin of Arabic khat: 1) some said that Arabic khat was a gift from Allah S.W.T. to men, like the sciences which had been taught to Prophet Adam and then passed down from generation to generation; 2) Ibn Khaldun said that the Arabic khat was a masnad type of writing system, which originated in Yemen, and then moved to the al-Munzir family in Herta. It was born during the time of Saba' and the Himyar Kingdom; 3) Some stated that Arabic khat came from Herat and eventually reached Hejaz; 4) Another opinion was that Arabic khat derived from Finiqi, which was taken from ancient Egyptian letters; and 5) some said it came from Nabati (Aramai) alphabet.

However, a considerable number of historians agree with the latter opinion. From Nabathi, which reached Hejaz through the near road (to Nabati, Batra, Ula, Medina, and Mecca) and the long road (through Harran to the valley of Furat, Daumatul Jandal, Medina, Mecca, and Taif). Nabathi writing system was a communication tool (language) of Nabthi tribe, which was one of the Arab ethnic groups (Sarif, 2016).

\section{Development of Arabic Khat}

Since the existence of Islam (6 CE) in the Arabian Peninsula, Arabic writing began to develop. The Arabic writing system was first used when recording the holy verses of al-Qur'an. At that time, Prophet Muhammad ordered his companions to write down all the sacred poetry of al-Qur'an revealed to him. From that moment, the Arabic alphabet was used to write poems of al-Qur'an on animal skins (such as sheep, goats, cows), leaves (such as date leaves), rocks, bones, etc.

By all means, in the beginning, Arabic writing was still using simple Arabic letters, and it was not as picturesque as today (Arabic calligraphy/Arabic khat). At the era of Uthman ibn Affan, the official writing of the verses of al-Qur'an began. At that time, the report used Mushaf Utsmani. It was an Arabic writing system where there was no harakat (syakl) in its report. It was then disseminated to Kufa, Mecca, Basra, and several other cities.

Hereafter, the writing of al-Qur'an used the Kufic script, Rayhani script, Tsuluth script, and finally Naskh script. Naskh script was the first to be used as a 
manuscript of al-Qur'an printed in Germany and then disseminated to Islamic countries other than Arab. (Yulika, 2016).

Arabic khat has undergone some development since the era of Ummayah (661-750 CE) in Damascus, Syria, until the Abbasid dynasty's reign (750-1258 CE) Baghdad. It was then continued developing in the era of the Fatimid dynasty (9691171 CE), Ayyubiyah (1171-1250 CE), Mameluk (1250-1517 CE) in Egypt, Ottoman Turkey (1299-1922 CE), and Safavid Persia (1500-1800 CE).

The description above showed how long the development of the art of Islamic calligraphy or Arabic khat transpired, as it was found in today's era (Yulika, 2016). The following were some of the histories of the development of Arabic calligraphy writing/Arabic khat:

\section{Umayyad Dynasty 661-750 CE (Early Development of Arabic Khat)}

At this period, Muslims were motivated to develop Arabic calligraphy because they considered that Arabic writing was related to sacred religious values. With this belief, Arabic calligraphy's function and status were highly lifted. The report was not just a means of communication, but it was also reckoned as sacred writing.

Several types of calligraphy were named after the city where the calligraphy developed. However, the difference in the name did not mean that it had different characteristics. It has been proven by history that only three main styles grew in Mecca and Medina: Mudawwar (circle), Mutsallats (triangle), and Tim (twins, which was structured from triangle and process).

The first person who was recognized as a calligraphy expert in this era was Qutbah al-Muharrir. He was often referred to as the famous calligrapher because of his skills and talents in developing cursive writing.

Qutbah discovered four kinds of new writing styles: Thumar, Jalil, Nisf, and Tsuluth. He was also called the most excellent calligrapher in the world because of his intelligence (Huda \& Muharsafa, 2010).

\section{Abbasid Dynasty 750-1258 CE}

At the beginning of the Abbasid dynasty's reign, two calligraphers were often mentioned in Arabic history. They were Addahak ibn 'Ajlan who lived during the first caliphate of Abbasid dynasty (Abul' Abbas as-Safah 750-754 CE) and Ishaq ibn Hammad who lived during the period of al-Mansur (754-775 CE) and the third Caliphate of the Abbasid dynasty (al-Mahdi 754-786 CE). Ishaq appeared prominently due to his achievements in embellishing Tsuluth and Tsulutsain's script and popularizing the use of those two scripts.

In the Abbasid dynasty's early days, there were also several other calligraphers such as Yusuf as-Sijli and al-Ahwal al-Muharrir. Yusuf as-Sijli learned the Tsuluth script from Ishaq, and then he was succeeded in creating more good writing than it was. On the other hand, al-Ahawal al-Muharrir was the disciple of Ibrahim. From the writing style of Tsuluth and Tsulutsain that he had learned from his teacher, he discovered a new technique which he called Nisf. Then the calligraphy traditions continued to be passed down to Ibn Muqlah, the al-Ahawal al-Muharrir. He was noted as one of the great calligraphers, and his name was often mentioned to this day. Since he was young, he had shown his accomplishment in this art of calligraphy. With his brother, Abu Abdullah, he became a prominent calligrapher of his time. He was the one who contributed to implementing the rules of writing 
Arabic letters based on geometric dimensions, which consisted of three elements, the point, the alif letter, and the circle. Furthermore, he was also done merit in pioneering the six major writings (al-aqlam as-sittah). An-Nadim (someone born when Ibn Muqlah was still alive) said that even though there were many distinguished calligraphers during the Abbasid dynasty, those who could achieve success and perfection were Ibn Muqlah and his brother Abu Abdullah.

Among some of Ibn Muqlah's renowned disciples were Ibn as-Simsimani and Muhammad ibn Asad. Through his two disciples, the ingenious knowledge of Ibn Muqlah was passed down to Ibn Bawwab, who died in 1022 CE. Ibn Bawwab developed calligraphy and perfected it based on the theory created by Ibn Muqlah. Ibn Bawwab especially had great concern for the improvement of Naskh and Muhaqqaq khat/script. After him came other calligraphers, such as Muhammad ibn Abdul Malik, Syuhdah ibn al-Ibar, Aminuddin Yaqut, Waliyyul 'Ajami, Affifudin Muhammad al-Halbi, Sheikh Imaduddin, Mas'ud ibn Muhammad al-Katib alAsfahani, and others.

In the following century came Yaqut al-Musta'simi. He introduced another new method to enrich Arabic writing. He gave new tenderness and elegance to the six major writing styles in that period. Therefore, Yaqut was known as the most excellent calligrapher at the Abbasid dynasty's end, which later fell by the Mughal dynasty in $1258 \mathrm{CE}$.

It was during the Caliphate of the Abbasid dynasty that calligraphy showed a natural diversity in its use. It was very different compared to the reign of the Umayyad dynasty. From the examples explained above, we could say that calligraphy as an architectural ornament and other purposes was very dominant (Huda \& Muharsafa, 2010).

\section{Calligraphy Development in Maghrib Region}

In the map of Islamic history, two main areas were identified in marking cultural differences during the Middle Ages: the Eastern region called al-Masyriq and the Western region called al-Maghrib. In the history of Islamic civilization development, the Maghrib country came up with many different forms of Islamic art, including calligraphy or khat.

The calligraphy that developed in this area was initially centered in Kairawan (now Tunisia), a city first built by the Arabs in 670 CE. The type of calligraphy made in this country was Kufic script because it aimed to differentiate the type of kufi that developed in Baghdad. Therefore, the khat/script was called Khat Kufi Maghribi. This Kufic script's main characteristics were the thick and sharp horizontal line at the end part and the arch of the letters of $y a^{\prime}$ and nun that protruded far below the line in a semicircle. Meanwhile, the letters $f a^{\prime}, \operatorname{mim}$, and wawu were stroked more roundly, and the vertical lines were taller and slimmer. This Kufic script's main characteristic would have a strong influence on the type or style of khat that was born afterward (Huda \& Muharsafa, 2010).

\section{Further Development on Types of Calligraphy}

In the $13^{\text {th }}$ century, along with the emergence of Yaqut al-Mustsimi in the eastern part of the al-Masyriq area, it was a century of destruction and rebuilding. The great invasion from the Mughal army, the subordinate of Hulagu Khan, succeeded in destroying Baghdad's city in 1258 CE. But after the destruction, Islam was able to revive in less than half a century. One of the factors was due to Hulagu 
Khan's great-grandson, Ghazan, who had embraced Islam. Under his leadership and the Khan II Dynasty banner, he rebuilt the collapsed Islamic culture, which his successor, Ulyatun, then continued. During his reign, scholars and artists received protection and good treatment and were continuously encouraged to be creative.

This dynasty lasted until the end of the $14^{\text {th }}$ century CE, which was later replaced by the Timurid dynasty. It was established by Timur Leng (died in 1405 CE), which was known to the world as the great destroyer. However, after he embraced Islam, artists and scholars received special treatment, and they were brought to Samarkand (the capital of this dynasty). He paid great attention to calligraphy's art, and he ordered to write a copy of al-Qur'an. This tradition was succeeded by his son, Shah Ruk (1405-1447 CE).

The Timurid dynasty began to decline near the $15^{\text {th }}$ century, and a new dynasty, Safavid, later replaced it. This dynasty was founded by Shah Ismail (15021524 CE). It lasted until 1736 CE in Persia and Iraq. During its development, one of the famous khat in this era was the Farsi script.

As for other areas, there was Mamluk Caliphate which ruled Egypt and Syria (1250-1517 CE). Behari-style calligraphy emerged in India in the $14^{\text {th }}$ century CE. Meanwhile, in the Islamic China area, there was also a calligraphy style that was influenced by Chinese letter brush strokes called Shini (Chinese style).

The subsequent development of calligraphy in the Arab region was during the Ottoman dynasty's reign in Turkey. During this dynasty, the calligraphers showed a lot of passion, enthusiasm, and remarkable imagination. The love of calligraphy was not only seen in calligraphy artists because some of the sultans in this dynasty were also known as calligraphers. The style or type of calligraphy used and developed during this dynasty was Farsi. Since the beginning of the Ottoman dynasty, the development of calligraphy in Turkey gave birth to many new styles. Some of the well-known styles or types of calligraphy were Syikastah, Syikastahamiz, Diwani, and Diwani-jali. (Huda \& Muharsafa, 2010).

\section{The Development of Calligraphy in Indonesia (Jakarta)}

Along with Islam's entry into Indonesia, Arabic art and culture were introduced to the residents, notably Arabic calligraphy or khat. Khat was the first Islamic cultural art form to be discovered, and it marked the entry of Islam into the Indonesian archipelago. This notion was confirmed by finding the tomb of Fatimah Binti Maimun in Gersik (d. 495 H/1082 CE) (Abubakar, 1991; Binti Mohamad et al., 2018).

The development of khat in Jakarta could not be separated from Islam's expansion in Indonesia (especially Jakarta). Islamic rulers led the city of Jakarta in the past, and they rendered the expansion of Islam rapidly, which resulted in the rapid development of khat. One way of spreading Islam in Jakarta was through arts and cultural activities such as Arabic calligraphy (khat). The events in this city certainly influenced the development of Islamic culture and Islamic preaching in Jakarta (Soraya, 2012).

\section{The Figures of Arabic Khat}

Along with its development, renowned and distinguished Arabic khat figures were born. They created many kinds of Arabic khat styles, which were still followed and used as guidelines by Arabic calligraphy artists worldwide. The following were some of the Arabic calligraphy/khat figures. 
Ibn Muqlah (Abu Ali al-Asdar Muhammad ibn al-Hasan ibn Abdullah ibn Muqlah) was born in $887 \mathrm{CE}$ and died in $940 \mathrm{CE}$. Because of his brilliance, he was named the "prophet" of calligraphers or iman al-khathathin (the calligraphers leader). He raised naskh khat into a popular calligraphy style. In the previous century, it was dominated by Kufic khat. Ibn Muqlah was a calligrapher who first proposed the Arabic script writing method. This new method was called al-khat almansubi (leaning calligraphy), which was very influential in Arabic calligraphy writing. (Soraya, 2012).

Another well-known calligrapher was Ibn Bawwab (Abu al-Hasan Ali ibn Hilal), who was nicknamed ibn bawwab because his father was a gatekeeper Baghdad Palace. He was one of the calligraphers who memorized al-Qur'an and wrote it in 64 manuscripts. One of the manuscripts was written in Rayhani style and was kept in Leila Istanbul. He died in 1022 CE. He was recognized as the successor of Ibn Muqlah, whereas he was a disciple of Muhammad ibn Asad. Initially, he was known as a home decorator who later also developed and embellished al-aqlam assittah. However, his attention was more devoted to naskh khat.

Besides Ibn Bawwab, there was also Musthafa al-Raqim, who was born in $1171 \mathrm{H}$ in Konya, Anatolia, Turkey. He became a calligrapher for Ottoman Empire during Salim III's reign (1789-1807 CE). He was nicknamed Rais al-Khathathin (Leader of the calligraphers).

Another notable calligrapher was Hamid al-Amidi/Hamid Aytac al-Amidi (Musa Azmi), born in 1891 CE. He had disciples scattered all over the world, and one of them was Hashim Muhammad al-Baghdadi. (Soraya, 2012).

There are many other calligraphers whose works were highly respected and recognized. The contemporary Islamic calligraphers who were well-known in Indonesia were as followed:

1. Didin Sirojuddin AR. He was known as the father of Indonesian calligraphy. He was born on July 15, 1957, in Kuningan, West Java. In 1985, he founded a calligraphy institute, LEMKA (Lembaga Kaligrafi Al-Qur'an/Al-Qur'an Calligraphy Institute) in Jakarta.

2. Achmad Nuril Mahyuddin. He was born in Lamongan. He was the founder of Wet Positive Abstract of Nurilist, a new treasury contribution to the richness of art globally, particularly Islamic calligraphy. His work was one of the world-class painting touch wonders born in Indonesia (Huda \& Muharsafa, 2010).

Apart from the two figures above, many other calligraphers in Indonesia were exceptionally talented in Islamic art, such as H. Abdul Manshur Dompu, Tubagus Dudum Sonjaya, Hatta Hambali, H. Darami Yunus, H. Azhar Noer, and so on. Causative Factors of Khat Rapid Development

A close relationship between khat and al-Qur'an was one factor that caused the rapid development of khat. Besides these factors, several other factors caused calligraphy to develop rapidly and spread in the Islamic world. They were the influence of power expansion, the kings and social elites' role, and the influence of science development.

The expansion of Islamic power and large-scale urbanization to the conquered areas had a significant influence on khat development. For example, the Umayyad dynasty conquered several regions, such as India, China, and others. During this dynasty, the government implemented policies with a familiar idea, 
which resulted in the spread of Arabic to the conquered territories. In certain areas, Arabic letters became non-Arabic characters, such as Turkish, Urdu, Persian, and Malay (Jawi).

On the other hand, the king and the social elites' role also influenced the development of khat. For example, the style of tumar (smooth sheet of tumar tree leaves) was created at the direct order of Muawiyah as the official writing of the Umayyad dynasty. The writers in that era were active in adorning the Arabic script.

Besides, the development of science also influenced the development of khat. It was started during the Umayyad dynasty that science developed rapidly. Paper was introduced to the Arabs from China in Samarkand in 133 H/751 CE. Paper's existence and availability were factors causing the development of writings, mainly Arabic scripts. Various calligraphy styles and types that existed previously had been redeveloped to be more refined. Not long afterward, different early calligraphy styles emerged. One of them was called al-Aqlam as-Sittah (six significant calligraphy types), consisting of tsuluth, naskh, muhaqqaq, rayhani, riqa, and tauqi (A. R., 2002).

Furthermore, Sarif (2016) added three other essential factors that supported the rapid development of Arabic khat. First, the motivation came from the verses of al-Qur'an, which had a strong influence and encouraged the calligraphers to improve the culture of writing. Second, there was an urge to write al-Qur'an, previously reported on date midribs and animal bones. Third, the language used in al-Qur'an was not ordinary Arabic. It was classified as high-level Arabic, which was full of meaning in every letter. Thus, Arabic khat art developed rapidly with real spiritual and aesthetic sense.

Khat has experienced various advances, such as the new patterns and forms and media originating from the development of Arabic calligraphy (Jaudi, 1998). The effect of khat affected Muslims' spiritual aspects, but it also influenced their social and cultural factors. The beauty of the khat should reflect the beauty of the soul and Muslims' behavior as the calligrapher. Thus, this kind of reflection should be echoed so that Muslims could become an example of good conduct.

The art of calligraphy had such a significant influence on al-Qur'an, which touched every Muslim life aspect. It elevated calligraphy to the pinnacle of art that was considered sacred (Redaktur, 2018). On the other hand, al-Qur'an khat's writing has encouraged Muslims to change the term of Arabic calligraphy to Islamic calligraphy. This was due to the significant role of Islam in developing Arabic calligraphy, so Islamic calligraphy term was more popular than the term of Arabic calligraphy art.

\section{Conclusion}

Arabic Khat began to grow and develop since the emergence of Islam in Arab in the $6^{\text {th }}$ century CE. The Arabic alphabet was first used at the time of recording the holy verses of al-Qur'an. Arabic khat started to develop centuries ago, which began during the reign of the Umayyad dynasty (661-750 CE), centered in the Syrian city of Damascus until the authority of the Abbasid dynasty (750-1258 CE), which central was in Baghdad. It then continued again during the reign of Fatimid (969$1171 \mathrm{CE}$ ) and the reign of Ayyub (1171-1250 CE). Three factors caused calligraphy to develop rapidly: the influence of power expansion, the kings and social elites' role, 
and the influence of science development. Moreover, the encouragement coming from the verses of al-Qur'an, the motivation to write al-Qur'an, and the use of Arabic as al-Qur'an language are also the factors in the development of Arabic khat. Hence, it is no wonder that the term Arabic khat is synonymous with al-Qur'an's khat.

\section{References}

A. R., Didin Sirojuddin. (2020). Peta Perkembangan Kaligrafi Islam di Indonesia. Buletin Al-Turas, 20(1), 219-232. https://doi.org/10.15408/bat.v20i1.3757

A. R., Didin Sirojudin. (1992). Dinamika Kaligrafi Islam. Darul Ulum Press.

A. R., Didin Sirojudin. (2002). Lukisan Tembok,Kaligrafi, dan Arabes: Dalam Ensiklopedi Tematis Dunia Islam. Ichtiar Baru Van Hoeve.

Abubakar, H. (1991). Sekilas Tentang Asal-Usul Huruf Arab dan Seni Kaligrafi di Indonesia. 2. https://jurnal.ugm.ac.id/jurnal-humaniora/article/view/2093

Alashari, D. M., Hamzah, Abd. R., \& Marni, N. (2019). Islamic Art and Language as a Source of Inspiration Leading to Traditional Arabic Calligraphy Art. UMRAN International Journal of Islamic and Civilizational Studies, 6(3), 33-45. https://doi.org/10.11113/umran2019.6n3.342

Auliya, A. G., \& Shokiyah, N. N. (2013). Estetika Seni Lukis Kaligrafi Karya Syaiful Adnan. Brikolase : Jurnal Kajian Teori, Praktik Dan Wacana Seni Budaya Rupa, 5(2). https://jurnal.isi-ska.ac.id/index.php/brikolase/article/view/417

BAYAR, A., \& SAMI, K. (2009). How a Font Can Respect Basic Rules of Arabic Calligraphy. International Arab Journal of E-Technology, 1(1). http://www.iajet.org/documents/vol.1/no.1/How\%20a\%20Font\%20Can \%20Respect\%20Basic\%20Rules\%20of.pdf

Binti Mohamad, K., Bin Osman, K., \& Bin Puteh, A. (2018). Sejarah Perkembangan Seni Khat Dalam Kesenian Islam di Nusantara. Fikiran Masyarakat, 6(1). https://kemalapublisher.com/index.php/fm/article/view/283

Hanifa, A. (2013, July 10). Sejarah dan Perkembangan Kaligrafi Arab. Republika. https://www.republika.co.id/berita/mppmdp/sejarah-dan-perkembangankaligrafi-arab

Huda, H. N., \& Muharsafa, S. (2010). Asyiknya Belajar Kaligrafi: Cara Praktis Belajar Kaligrafi. Afkari Publishing.

Ikhwan, I., Sutirman, M., \& Putrisari, N. D. (2017). Pengembangan Kapasitas Masyarakat dalam Seni Kaligrafi di Lingkungan RW 04 Desa Cipacing, Jatinangor, Sumedang. Dharmakarya: Jurnal Aplikasi Ipteks Untuk Masyarakat, http://jurnal.unpad.ac.id/dharmakarya/article/view/14722

Iskandar, T. (1989). Kamus Dewan. Dewan Bahasa dan Pustaka.

Jaudi, M. husain. (1998). Al-Fann al-'Arabi al-Islami. Dar al-Mashirah.

Madkur, I. (1995). Mu'jam al-Wajiz. Majma' al-Lughah. 
Mansour, K. (n.d.). On the Origin of Arabic Script. 245-255. https://doi.org/10.36824/2018-graf-mans

Maryono, M. (2018). Nilai-nilai Pendidikan dalam Seni Kaligrafi Karya Syaiful Adnan. Wahana Islamika: Jurnal Studi Keislaman, 4(1). http://wahanaislamika.ac.id/index.php/WahanaIslamika/article/view/14

Ni'mah, K. (2019). Khat dalam Menunjang Kemahiran Kitabah Bahasa Arab. DAR ELILMI : Jurnal Studi Keagamaan, Pendidikan Dan Humaniora, 6(2). http://ejurnal.unisda.ac.id/index.php/dar/article/view/1724

Patriani, S. R. (2017). Pengaruh Sosiokultural Budaya Islam terhadap Seni Lukis Kaligrafi di Indonesia. Jurnal Buana Pendidikan, 12(23).

Pujiati, P. (2016). Kaligrafi Arab Digital Ayat Al-Qur'an di Dunia Maya. MIQOT: Jurnal Ilmu-Ilmu Keislaman, 40(1). https://doi.org/10.30821/miqot.v40i1.248

Redaktur. (2018, October 22). Sejarah Perkembangan Kaligrafi Islam. http://amalud.com/sejarah-perkembangan-kaligrafi-islam/

Sadewa, A. (2018). Kajian Jenis Khat, Media dan Warna Kaligrafi Arab di Masjid Keramat Desa Pulau Tengah Kabupaten Kerinci Provinsi Jambi. Serupa: The Journal of Art Education, 6(2).

Sarif, D. (2016). Pengaruh Alquran terhadap Perkembangan Kaligrafi Arab. ETNOHISTORI: Jurnal Ilmiah Kebudayaan Dan Kesejarahan, 3(2). http://ejournal.unkhair.ac.id/index.php/etnohis/article/view/848

Soraya, S. (2012). Nilai dan Makna Kaligrafi Arab pada Masjid Al-Atiq (Analisis Estetik). Students E-Journals, http://jurnal.unpad.ac.id/ejournal/article/view/1693

Teparic, M. (2014). Figural Representation in the Arabic Calligraphy. Epiphany, 6(2). https://doi.org/10.21533/epiphany.v6i2.77

Yaghan, M. A. J. (2020). Mathematical concepts in Arabic calligraphy: The proportions of the 'Alif. PLOS ONE, 15(5), e0232641. https://doi.org/10.1371/journal.pone.0232641

Yulika, F. (2016). Jejak Seni dalam Sejarah Islam. Institut Padangpanjang.

\section{Copyright Notice}

Authors retain copyright and grant the journal the right of first publication with the work simultaneously licensed under a Creative Commons Attribution 4.0 International License that allows others to share the work with an acknowledgment of the work's authorship and initial publication in this journal.

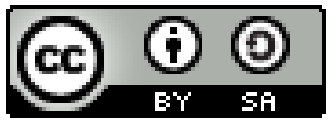




\section{THIS PAGE INTENTIONALLY LEFT BLANK}

Jurnal Ilmiah Program Studi Pendidikan Bahasa Arab IAIN Palangka Raya Vol. 9, No. 1 / 13-24 Al-Ta'rib | p-ISSN 2354-5887 | e-ISSN 2655-5867 